University of St. Thomas, Minnesota

UST Research Online

Finance Faculty Publications

Finance

2017

Contagion of the Eurozone Debt Crisis

Lalith P. Samarakoon

University of St. Thomas, Ipsamarakoon@stthomas.edu

Follow this and additional works at: https://ir.stthomas.edu/ocbfincpub

Part of the Finance and Financial Management Commons

This Article is brought to you for free and open access by the Finance at UST Research Online. It has been accepted for inclusion in Finance Faculty Publications by an authorized administrator of UST Research Online. For more information, please contact asle4660@stthomas.edu. 


\title{
Contagion of the eurozone debt crisis
}

\author{
Lalith P. Samarakoon ${ }^{1}$ \\ Department of Finance, Opus College of Business, University of St. Thomas, 2115 Summit Ave., St. Paul, MN 55105, United States
}

\section{A R T I C L E I N F O}

\section{Article history:}

Received 20 February 2015

Received in revised form 9 March 2017

Accepted 20 March 2017

Available online 21 March 2017

\section{JEL classification:}

F3

F30

F36

G01

G15

Keywords:

Eurozone debt crisis

Contagion

Sovereign bond yields

Stock returns

Risk-on risk-off hypothesis

Decoupling hypothesis

\begin{abstract}
A B S T R A C T
This paper examines the contagion of the eurozone debt crisis to developed and emerging stock markets around the world. Using the VAR methodology, and changes in sovereign bond yields and stock returns of the crisis countries as proxies for the eurozone debt crisis, this paper finds strong and pervasive evidence of negative contagion from the crisis countries to other stock markets. Consistent with risk-on risk-off hypothesis, changes in sovereign bond yields of crisis countries impact stock returns positively during normal times and negatively during the crisis, providing strong evidence of negative contagion. The impact of equity returns of crisis countries on other equity markets is large and positive during normal times and less positive during the crisis, suggesting evidence of negative contagion and decoupling of stock markets during the crisis. The Asian markets do not show pervasive evidence of contagion from the eurozone crisis.
\end{abstract}

(c) 2017 Elsevier B.V. All rights reserved.

\section{Introduction}

The eurozone debt crisis has been the dominant economic and financial event in the most recent economic history of the world. This crisis is primarily about unsustainable budget deficits and government debt of a number of eurozone nations, and as such this is the first experience with an economic crisis in a currency union in the modern history of the world. Concerns about an impending debt crisis began to surface around November 2009 after Greece announced previously undisclosed large budget deficits. Over the subsequent three years, deficit and debt concerns spread to Ireland, Portugal, Italy, Spain and Cyprus. Greece, Ireland and Portugal received bailouts by the IMF and the European Commission. The crisis-hit countries began implementing various financial and economic reforms that include large austerity programs. The most visible facets of the crisis have been sharp increases in sovereign bond yields of crisis countries (see Fig. 1), stock market volatility (see Fig. 2), and anti-austerity protests and social unrests. Concerns over possible break-up of the eurozone and the high sovereign bonds yields began to dissipate in July 2012 with the promise by the ECB president Mario Draghi to do "whatever it takes to preserve the euro."

\footnotetext{
${ }^{1}$ I wish to thank the participants of the 2014 European Financial Management Conference in Rome, Italy, 2014 International Finance and Banking Society Conference in Lisbon, Portugal and for an anonymous referee for useful comments.

E-mail address: lpsamarakoon@stthomas.edu
} 


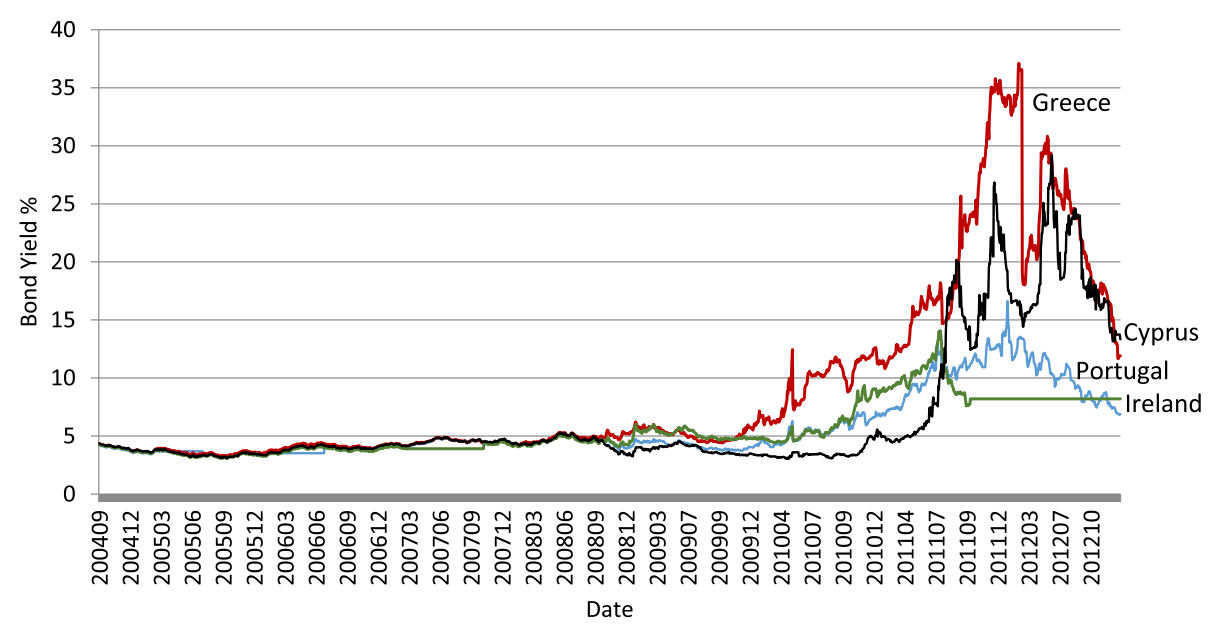

Fig. 1. Daily sovereign bond yields of crisis countries (November 2004-December 2012).

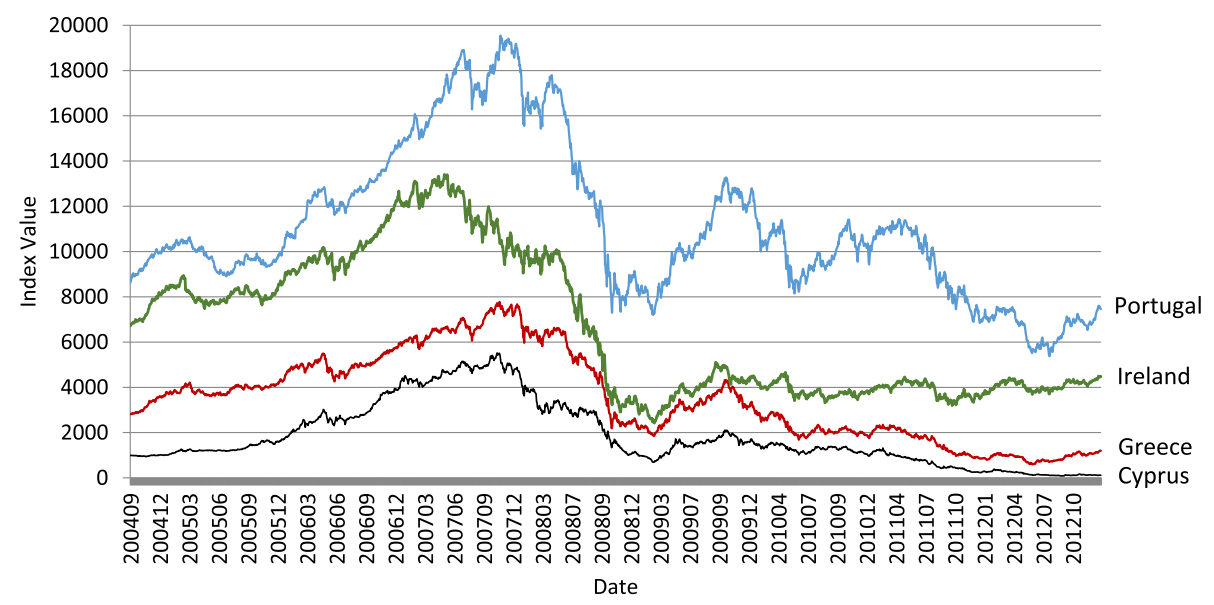

Fig. 2. Daily stock market indices of the crisis countries (November 2004-December 2012).

The eurozone debt crisis provides a unique opportunity to examine the spillover of a debt crisis associated with a currency union to equity markets around the world. Specifically, this study raises the following empirical questions. How did the eurozone debt crisis affect stock markets around the world? Is there evidence of contagion of the debt crisis to other markets? If so, what is the nature and magnitude of such contagion? By investigating these questions, this paper sheds light on the impact of the eurozone debt crisis on all developed and emerging stock markets.

The importance of understanding the nature and the extent of contagion of the eurozone debt crisis has been underscored out by many researchers and policy makers. Glover and Richards-Shubik (2014) point out that existing assessments of contagion in the European debt crisis are limited and primarily descriptive in nature and that quantifying the risk of such spillovers is necessary to assess whether the benefits of a sovereign bailout outweigh the costs. Black et al. (2013) also point out that understanding contagion is crucial given that sovereign defaults potentially pose systemic risks to banks and the overall financial system. Constancio (2012) emphasizes that contagion is crucial for policy-making, and that crisis management by all competent authorities should focus on the policy measures that are able to contain and mitigate contagion. Further, Missio and Watzka (2011) highlight that identification of contagion effects are crucial for the choice and timing of policy intervention. Hence, a study of contagion of the eurozone debt crisis enhances our understanding of the magnitude and effects of spillover of debt crisis to other countries and provides important insights into the design of appropriate policy measures to deal with such crisis.

Contagion has been defined in much of the empirical literature as a significant increase in cross-market linkages after a shock to one market or group of markets. ${ }^{2}$ Consistent with literature, this paper defines contagion as the incremental impact of

\footnotetext{
${ }^{2}$ See, for example, Forbes and Rigobon (2002) and Bekaert et al. (2005).
} 
the crisis relative to what is expected during relatively tranquil times. ${ }^{3}$ Previous studies on international transmission of shocks have employed several methodologies for estimating contagion. They include models that use cross-market correlations or variants thereof, ARCH and GARCH models, cointegration techniques, and regressions and vector autoregressions (VAR) frameworks to estimate contagion. ${ }^{4}$

The approach taken by this paper falls into the latter category of VAR-based techniques. This paper specifies a VAR framework that relates equity returns in a given market to proxies for the debt crisis, directly measures the sensitivity of equity returns to proxies for the eurozone debt crisis during normal and crisis periods, and thereby estimates contagion as the incremental change in the sensitivity during the crisis period. This framework accounts for lagged effects of own market returns, thus allowing for any potential autocorrelations of a market's own returns. It also allows for differences in trading hours between Europe and the rest of the world markets through a proper lag structure for overlapping and non-overlapping markets. This methodology has the advantage of being straightforward and provides direct estimates of the transmission of shocks during normal and crisis times, enabling a complete understanding of the direction and the magnitude of contagion.

The methodology of this paper is implemented using a comprehensive sample of all the developed and emerging of stock markets. The eurozone debt crisis is measured by two metrics - the changes in sovereign bond yields of a portfolio of crisishit countries, and stock returns of a portfolio of crisis-hit countries. For the purpose of this study, the crisis countries include Greece, Ireland, Portugal and Cyprus. Then, the study estimates the impact of the two measures of the crisis on equity markets around the world both during a relatively normal period and the period of the eurozone debt crisis to understand the nature and severity of the contagion of the crisis.

This paper contributes to the literature in a number of important ways. The first contribution is to develop a straightforward framework for understanding contagion of the eurozone debt crisis. The second contribution of this paper is to provide empirical evidence on the contagion from the crisis countries to other developed and emerging stock markets. The third contribution is to uncover very strong evidence on the relation between changes in sovereign bond yields of crisis countries and equity returns, and stock returns in crisis hit countries and stock returns in other markets during the eurozone crisis relative to the non-crisis period.

The main results of this paper show that changes in sovereign bond yields of crisis countries are strongly positively associated with equity returns during normal times, and this large positive effect reverses to a large negative effect during the eurozone crisis providing strong evidence of contagion and spillover of economic uncertainty from crisis countries to equity markets. This evidence is consistent with the "risk-on risk-off hypothesis" where investors tend to engage in high-risk investments when risk is perceived as low and exit from risky investments when risk is perceived as high. Further, the results show that equity returns of crisis countries and the other markets are strongly positively related during normal times, and this relation becomes significantly less positive during the debt crisis. This evidence supports the "decoupling hypothesis" in that during the eurozone debt crisis equity markets around the world became less sensitive to the performance of the equity markets of the crisis countries relative to the more robust positive relation observed during normal times.

The rest of this paper is organized as follows. Section 2 provides a detailed description of the VAR framework employed in this paper to estimate contagion. Section 3 presents data and summary statistics. Section 4 provides a discussion of empirical results and policy implications while Section 5 provides the conclusions.

\section{The methodology}

\subsection{Proxies for the eurozone debt crisis}

Two variables are used as proxies for the eurozone debt crisis. The first variable is sovereign bond yields of crisis countries. When the perceived probability of sovereign debt defaults increases, sovereign bond yields increase. The changes in sovereign bond yields of crisis countries reflect the changes in investor attitude towards risks of such sovereign bonds and provide an excellent proxy for the debt crisis. The second proxy is equity returns of crisis countries. As with sovereign bond yields, equity markets of crisis countries react to changes in investor assessment of risks associated with intensifying financial crisis and weakening macroeconomic, political and social conditions of the crisis nations. Therefore, stock returns of crisis countries can be used as a variable to capture the debt crisis.

Although six countries, i.e. Greece, Ireland, Portugal, Cyprus, Italy and Spain, have been associated with sovereign debt problems, the crises in Italy and Spain did not reach the level of severity experienced by the other four countries. Greece, Ireland and Portugal have had to be bailed out by the IMF and the European Commission. Cyprus also had to receive emergency assistance from the IMF. The eurozone debt crisis mostly reflected the debt problems faced by Greece, Ireland, Portugal and Cyprus. Hence, this study defines the crisis countries as consisting of these four countries.

\footnotetext{
${ }^{3}$ See Samarakoon (2011), Karolyi (2003), Forbes and Rigobon (2001) and Edwards (2000) for a discussion of definitions and measurements of contagion.

${ }^{4}$ For example, King and Wadhwani (1990), Lee and Kim (1993), Karolyi and Stulz (1996), and Forbes and Rigobon (2002) use cross-market correlations, Hamao et al. (1990), Lin et al. (1994), Baele (2005), and Bekaert et al. (2005) use the GARCH framework, Longin and Solnik (1995) employs cointegration, and Eun and Shim (1989), Bae et al. (2003), Cuadro-Saez et al. (2009), and Samarakoon (2011) use regressions and VAR models to estimate contagion.
} 


\subsection{Testing contagion}

The transmission of shocks from sovereign bond markets to equity markets is examined by estimating the sensitivity of stock returns of a given country to changes in bond yields of an equally-weighted portfolio of sovereign bond yields of the four crisis countries. The transmission of shocks from the equity markets of crisis countries to other equity markets is estimated by the sensitivity of stock returns of a given country to stock returns of an equally-weighted portfolio of equity returns of the four crisis countries. ${ }^{5}$

For overlapping markets, the relationship between stock returns on the one hand, and changes in bond yields or stock returns of crisis countries on the other hand is contemporaneous. This is because information about the behavior of bond yields and stock markets of crisis-hit countries on a given day is known to overlapping equity markets on the same trading day. In contrast, non-overlapping markets become fully informed about the behavior of bond and stock markets of crisis countries on a given day with a one-day lag. As a consequence, one would expect to observe non-overlapping equity markets to be related to lagged changes in bond yields and lagged stock returns of crisis countries.

The relation between stock returns and changes in bond yields and stock returns of crisis countries is specified using the following two vector autoregressive models for each equity market. Model (1) applies to overlapping markets, and Model (2) applies to non-overlapping markets.

$$
\begin{aligned}
& \mathrm{R}_{\mathrm{t}}=\alpha+\sum_{\mathrm{j}=1}^{2} \beta_{\mathrm{j}}\left(\mathrm{R}_{\mathrm{t}-\mathrm{j}}\right)+\lambda_{1}\left(\mathrm{X}_{\mathrm{t}}\right)+\lambda_{2}\left(\mathrm{X}_{\mathrm{t}-1}\right)+\mu\left(\mathrm{DUS}_{\mathrm{t}}\right)+\varepsilon_{\mathrm{t}} \\
& \mathrm{R}_{\mathrm{t}}=\alpha+\sum_{\mathrm{j}=1}^{2} \beta_{\mathrm{j}}\left(\mathrm{R}_{\mathrm{t}-\mathrm{j}}\right)+\lambda_{1}\left(\mathrm{X}_{\mathrm{t}-1}\right)+\lambda_{2}\left(\mathrm{X}_{\mathrm{t}-2}\right)+\mu\left(\mathrm{DUS}_{\mathrm{t}}\right)+\varepsilon_{\mathrm{t}}
\end{aligned}
$$

$R_{t}$ is the daily stock return of a given national equity market. X represents the change in the average daily bond yield of crisis countries, $\Delta \mathrm{BY} \mathrm{M}_{\mathrm{M}}$, or the average daily stock returns of crisis countries, $\mathrm{R}_{\mathrm{M}}$. Returns and yields are continuously compounded. DUS is a dichotomous dummy variable that is used to control for the effects of the U.S. subprime crisis on equity returns. It takes the value of one during the period from 9/01/2008 to 03/09/2009 and zero otherwise. The subscript $t$ represents the trading day, $\alpha$ is the intercept, and $\varepsilon_{t}$ is the error term of the regressions.

The VAR models incorporate two lags of own market returns designed to capture the lagged influence of own-market returns. The number of lags is based on the Akaike Information Criterion (AIC) and Bayesian Information Criterion (BIC). Additionally, preliminary estimations of the models indicated that the third lag of own returns is not significant across most markets. As a result, the models specify two lags of own market returns for all the markets examined. The results are robust to the inclusion of additional lags.

The influence of the sovereign bond market of crisis countries on other equity markets is captured by the contemporaneous change in the average sovereign bond yield $\left(\Delta \mathrm{BY}_{\mathrm{M}, \mathrm{t}}\right)$ of crisis countries for overlapping markets, and by the lagged change in the average sovereign bond yield $\left(\left(\Delta \mathrm{BY}_{\mathrm{M}, \mathrm{t}-1}\right)\right.$ of crisis countries for the non-overlapping markets. Similarly, the influence of the equity market of crisis countries on other equity markets is estimated using the concurrent average equity market return of crisis countries $\left(\mathrm{R}_{\mathrm{M}, \mathrm{t}}\right)$ for overlapping markets, and through lagged average equity market return of crisis countries $\left(\mathrm{R}_{\mathrm{M}, \mathrm{t}-1}\right)$ for non-overlapping markets. The coefficient $\lambda_{1}$ measures the spillover effect of the crisis from the bond market or the equity market of crisis countries to other equity markets, capturing the same trading day effect of the crisis on overlapping markets and the next trading day effect on non-overlapping markets. To provide for the possibility that the impact of bond yield shocks or equity market returns originated in the crisis countries on a given trading day is incorporated into stock prices of other markets over a period of two days, both models include an additional lag of $\Delta B Y_{M}$ and $R_{M}$. The coefficient $\lambda_{2}$ associated with $\mathrm{X}_{\mathrm{t}-1}$ for overlapping markets in Eq. (1) and $\mathrm{X}_{\mathrm{t}-2}$ for non-overlapping markets in Eq. (2) captures this delayed spillover effect. The empirical estimations of the two equations indicated that the delayed effect is small and not statistically significant except for a very small number of markets. As a result, for the sake of efficiency, the estimated of $\lambda_{2}$ are not reported and the paper focuses on the estimates of $\lambda_{1}$.

The two models are estimated for normal and crisis periods separately. The coefficient $\lambda_{1}$, estimated during the normal period, captures the impact of sovereign bond or equity markets of crisis countries on other equity markets during normal times. The same coefficient estimated during the crisis time period measures the impact of sovereign bond or equity markets of crisis countries on other equity markets during the eurozone debt crisis. A significant changes in $\lambda_{1}$, if any, between the normal and crisis periods will provide evidence of contagion of the debt crisis to other equity markets. In order to measure the magnitude of contagion, each of the above two models is augmented by including an interaction dummy to capture the incremental impact of the eurozone crisis through sovereign bond yield and national stock market returns and estimated for the whole sample period that includes both the normal and crisis periods. Specifically, the VAR specification for measuring contagion takes the following form.

$$
\mathrm{R}_{\mathrm{t}}=\alpha+\sum_{\mathrm{j}=1}^{2} \beta_{\mathrm{j}}\left(\mathrm{R}_{\mathrm{t}-\mathrm{j}}\right)+\lambda_{1}\left(\mathrm{X}_{\mathrm{t}}\right)+\lambda_{2}\left(\mathrm{X}_{\mathrm{t}-1}\right)+\mu\left(\mathrm{DUS}_{\mathrm{t}}\right)+\delta\left(\mathrm{X}_{\mathrm{t}} * \mathrm{DEZ}\right)+\varepsilon_{\mathrm{t}}
$$

\footnotetext{
${ }^{5}$ The models were also estimated with equity market shocks rather than equity returns. They produced similar results.
} 


$$
\mathrm{R}_{\mathrm{t}}=\alpha+\sum_{\mathrm{j}=1}^{2} \beta_{\mathrm{j}}\left(\mathrm{R}_{\mathrm{t}-\mathrm{j}}\right)+\lambda_{1}\left(\mathrm{X}_{\mathrm{t}-1}\right)+\lambda_{2}\left(\mathrm{X}_{\mathrm{t}-2}\right)+\mu\left(\mathrm{DUS}_{\mathrm{t}}\right)+\delta\left(\mathrm{X}_{\mathrm{t}-1} * \mathrm{DEZ}\right)+\varepsilon_{\mathrm{t}}
$$

DEZ is defined as the eurozone crisis dummy, which takes a value of 1 during the crisis and 0 during the normal times. For overlapping markets (Model 3), the interaction of the concurrent $\mathrm{X}_{\mathrm{t}}$ variable, $\Delta \mathrm{BY} \mathrm{M}_{\mathrm{M}, \mathrm{t}}$ or $\mathrm{R}_{\mathrm{M}, \mathrm{t}}$, with DEZ captures the incremental impact, i.e. contagion, of $X_{t}$ on stock returns that is attributable to the crisis. In the same manner, for non-overlapping markets (Model 4), the interaction of the concurrent $X_{t-1}$ variable, $\Delta B Y_{M, t-1}$ or $R_{M, t-1}$, with DEZ captures the incremental impact of $X_{t-1}$ on stock returns that is attributable to the crisis. In other words, the coefficient $\delta$ measures the difference between the spillover effects during the normal times vs. crisis times. As such, the coefficient $\delta$ measures the contagion.

Another important aspect of interest is whether there exists a cause and effect relationship between stock returns of noncrisis countries, i.e., the dependent variables, on the one hand and sovereign bond yields and stock returns of crisis countries, i.e., independent variables, on the other hand. The potential causality is tested trough the Granger Test. Specifically, the Granger causality test measures whether stock returns of a particular country are caused by the changes in sovereign bond yields of crisis countries in Model (1) and stock returns of crisis countries in Model (2). Statistically significant coefficients associated with changes in sovereign bond yields and stock returns of crisis countries are interpreted as evidence of causality. This study reports the p-values associated with Granger tests for the two models. The VAR system is estimated using the Ordinary Least Squares, and standard errors are adjusted for heteroscedasticity using the White technique.

\section{Data}

The data comprises of daily stock price indices of all developed and emerging markets and daily sovereign bond yields of the six countries (Greece, Ireland, Italy, Portugal, Spain and Cyprus) that have been the source of the eurozone debt crisis. The source of the data is Bloomberg. The stock market indices represent price indices and are measured in U.S. dollar terms. The daily market indices represent 52 markets consisting of 27 developed and 25 emerging stock markets. This market classification is based on the MSCI list of developed and emerging stock markets. However, this study has expanded the MSCI emerging market list by adding Estonia, Malta, Slovakia and Slovenia, although technically these markets are frontier markets. The reason for this addition is that these four markets are part of the eurozone, and it is important to include all eurozone markets in this study. ${ }^{6}$ The returns are computed as changes in price indices and do not include dividends. All returns are continuously compounded.

The sample and summary statistics are shown in Table 1 . The total sample period is from 11/01/2003 to 12/31/2012. The eurozone crisis period is defined as the 33-month period from November 2009 to July 2012. The period of six years before the crisis period, i.e., 11/01/2003 to 10/31/2009, is considered the normal or the non-crisis period. One of the key events of an impending Greek crisis occurred on October 18, 2009 when Greek Prime Minister George Papandreou of the New Socialist government revealed that the budget deficit is set to rise to at least $12 \%$ of the GDP, double the previous government's estimate, because of earlier undisclosed debt. Although Ireland began experiencing its banking crisis from September 2008, the markets, particularly sovereign bond yields of crisis-prone countries, began to reflect potential risk of a broader debt crisis in a measurable manner with the unfolding of events relating to the Greek sovereign debt. Therefore, for the purpose of this study, November 2009 marks the start of the crisis period. The ECB President Mario Draghi's famous remarks that "within our mandate, the ECB is ready to do whatever it takes to preserve the euro. And believe me, it will be enough" on July 26, 2012 was a turning point in the market sentiment on the crisis. Although the underlying fundamental debt problems have not been solved, the confidence created by Draghi's statement has seen its effects through declining sovereign bond yields of crisis-hit countries since the statement. Therefore, July 2012 is considered the end of crisis period in this study. The period from August 2012 to December 2012 forms a part of the normal, non-crisis period along with six years before the beginning of the crisis.

It is also important to consider the differences in trading hours between the European and the rest of the markets. In this study, markets are classified as overlapping markets and non-overlapping markets, based on the time each market opens and closes for trading relative to the Central European Time (CIT). The overlapping markets are the ones which substantially overlap trading hours with the European exchanges. These markets open either just a short time before, concurrently with or after the opening of European stock markets. As a result, these markets substantially overlap trading hours with the European markets. There are 39 overlapping markets which are located in Europe, Middle-east and Africa, North America and South America. Non-overlapping markets open and close before the European markets open for trading or minimally overlap their latter part of trading day with the early part of trading in European markets. ${ }^{7}$ These markets are mainly located in Asia, and the sample includes 13 such non-overlapping markets.

\footnotetext{
${ }^{6}$ Slovenia and Slovakia joined the eurozone on 01/01/2007 and 01/01/2009 respectively and may not be considered "emerging economies." However, for the purpose of this study, "emerging markets" are defined as emerging stock markets classified as such by MSCI. According to the MSCI classification, Slovenia is a frontier stock market while Slovakia does not qualify as a frontier market. Other classifications such as Standard and Poor's, Dow Jones and Russel categorize both Slovenia and Slovakia as frontier markets.

${ }^{7}$ The amount of overlap of trading is one hour for Indonesia, Malaysia and Singapore, one-and-half hours for Thailand and two hours for India. All other developed and emerging Asian markets close either before or concurrently with the opening of European exchanges in the CET time-zone.
} 
Table 1

Summary statistics.

\begin{tabular}{|c|c|c|c|c|c|c|c|c|c|c|c|}
\hline \multirow[t]{2}{*}{ Country } & \multirow[t]{2}{*}{ Market index } & \multicolumn{2}{|c|}{$\rho(\mathrm{R}, \Delta \mathrm{BY} \mathrm{m})$} & \multicolumn{2}{|c|}{$\rho\left(\mathrm{R}, \mathrm{R}_{\mathrm{m}}\right)$} & \multicolumn{2}{|c|}{$\begin{array}{l}\text { Daily mean return } \\
(\%)\end{array}$} & \multicolumn{2}{|c|}{$\begin{array}{l}\text { Daily standard } \\
\text { deviation (\%) }\end{array}$} & \multicolumn{2}{|l|}{ \# Obs } \\
\hline & & $\begin{array}{l}\text { Normal } \\
\text { period }\end{array}$ & $\begin{array}{l}\text { Crisis } \\
\text { period }\end{array}$ & $\begin{array}{l}\text { Normal } \\
\text { period }\end{array}$ & $\begin{array}{l}\text { Crisis } \\
\text { period }\end{array}$ & $\begin{array}{l}\text { Normal } \\
\text { period }\end{array}$ & $\begin{array}{l}\text { Crisis } \\
\text { period }\end{array}$ & $\begin{array}{l}\text { Normal } \\
\text { period }\end{array}$ & $\begin{array}{l}\text { Crisis } \\
\text { period }\end{array}$ & $\begin{array}{l}\text { Normal } \\
\text { period }\end{array}$ & $\begin{array}{l}\text { Crisis } \\
\text { period }\end{array}$ \\
\hline \multicolumn{12}{|c|}{ Europe: Developed } \\
\hline Austria & ATX Prime Index & 0.05 & -0.23 & 0.79 & 0.73 & 0.059 & -0.050 & 1.92 & 1.98 & 1586 & 682 \\
\hline Belgium & Bel 20 Index & 0.07 & -0.24 & 0.79 & 0.74 & 0.030 & -0.033 & 1.51 & 1.76 & 1643 & 707 \\
\hline Cyprus & $\begin{array}{l}\text { Cyprus SE } \\
\text { General Index }\end{array}$ & -0.01 & -0.20 & 0.82 & 0.84 & 0.048 & -0.411 & 2.55 & 3.34 & 1396 & 688 \\
\hline Denmark & $\begin{array}{l}\text { OMX Copenhagen } \\
20 \text { Index }\end{array}$ & 0.09 & -0.23 & 0.76 & 0.69 & 0.035 & 0.032 & 1.64 & 1.60 & 1609 & 688 \\
\hline Finland & $\begin{array}{l}\text { OMX Helsinki } 25 \\
\text { Index }\end{array}$ & 0.07 & -0.23 & 0.79 & 0.70 & 0.040 & -0.018 & 1.72 & 2.02 & 1613 & 692 \\
\hline France & CAC 40 Index & 0.09 & -0.22 & 0.79 & 0.74 & 0.029 & -0.038 & 1.66 & 1.98 & 1643 & 707 \\
\hline Germany & $\begin{array}{l}\text { Deutsche Borse } \\
\text { Stock Index }\end{array}$ & 0.07 & -0.19 & 0.75 & 0.72 & 0.050 & 0.006 & 1.64 & 1.86 & 1632 & 703 \\
\hline Greece & $\begin{array}{l}\text { ASE General } \\
\text { Index }\end{array}$ & 0.02 & -0.25 & 0.90 & 0.92 & 0.060 & -0.244 & 1.78 & 2.67 & 1603 & 689 \\
\hline Iceland & ICEX Main Index & 0.01 & -0.11 & 0.10 & 0.38 & -0.117 & 0.045 & 3.69 & 1.06 & 1594 & 688 \\
\hline Ireland & ISE Overall Index & 0.06 & -0.20 & 0.81 & 0.74 & -0.008 & -0.011 & 1.82 & 1.79 & 1626 & 696 \\
\hline Italy & $\begin{array}{l}\text { FTSE Italia All- } \\
\text { Share Index }\end{array}$ & 0.06 & -0.22 & 0.79 & 0.72 & 0.019 & -0.085 & 1.63 & 2.15 & 1633 & 702 \\
\hline Luxembourg & LuxX Index & 0.06 & -0.22 & 0.72 & 0.65 & 0.037 & -0.034 & 1.66 & 1.67 & 1613 & 696 \\
\hline Netherlands & AEX-Index & 0.09 & -0.22 & 0.79 & 0.73 & 0.016 & -0.015 & 1.68 & 1.69 & 1643 & 707 \\
\hline Norway & OBX Index & 0.08 & -0.18 & 0.70 & 0.68 & 0.070 & 0.032 & 2.34 & 2.11 & 1613 & 692 \\
\hline Portugal & PSI 20 Index & 0.03 & -0.29 & 0.81 & 0.77 & 0.047 & -0.107 & 1.38 & 1.78 & 1643 & 707 \\
\hline Spain & IBEX 35 Index & 0.07 & -0.23 & 0.79 & 0.71 & 0.060 & -0.101 & 1.66 & 2.20 & 1626 & 703 \\
\hline Sweden & $\begin{array}{l}\text { OMX Stockholm } \\
30 \text { Index }\end{array}$ & 0.08 & -0.21 & 0.74 & 0.67 & 0.037 & 0.023 & 1.97 & 2.07 & 1613 & 692 \\
\hline Switzerland & $\begin{array}{l}\text { Swiss Market } \\
\text { Index }\end{array}$ & 0.06 & -0.20 & 0.74 & 0.64 & 0.036 & 0.010 & 1.33 & 1.30 & 1613 & 695 \\
\hline $\begin{array}{l}\text { United } \\
\text { Kingdom }\end{array}$ & FTSE 100 Index & 0.10 & -0.21 & 0.77 & 0.67 & 0.013 & 0.009 & 1.56 & 1.45 & 1623 & 692 \\
\hline \multicolumn{12}{|c|}{ Europe: Emerging } \\
\hline $\begin{array}{l}\text { Czech } \\
\text { Republic }\end{array}$ & Prague SE Index & 0.03 & -0.21 & 0.72 & 0.71 & 0.077 & -0.055 & 2.07 & 1.86 & 1611 & 692 \\
\hline Hungary & $\begin{array}{l}\text { Budapest SE } \\
\text { Index }\end{array}$ & 0.05 & -0.23 & 0.63 & 0.65 & 0.064 & -0.053 & 2.32 & 2.52 & 1604 & 694 \\
\hline Poland & Warsaw SE Index & 0.05 & -0.21 & 0.70 & 0.69 & 0.075 & -0.015 & 2.00 & 2.03 & 1610 & 691 \\
\hline Russia & $\begin{array}{l}\text { Micex Russian } \\
\text { Composite }\end{array}$ & 0.07 & -0.15 & 0.59 & 0.60 & 0.069 & 0.004 & 2.83 & 2.04 & 1588 & 679 \\
\hline Turkey & ISE National 100 & 0.08 & -0.16 & 0.59 & 0.56 & 0.080 & 0.019 & 2.61 & 1.95 & 1606 & 695 \\
\hline \multicolumn{12}{|c|}{ Europe: Frontier } \\
\hline Estonia & $\begin{array}{l}\text { OMX Tallinn } \\
\text { Index }\end{array}$ & -0.02 & -0.17 & 0.51 & 0.51 & 0.053 & 0.039 & 1.41 & 1.61 & 1618 & 692 \\
\hline Malta & MALTEX Index & 0.00 & -0.14 & 0.51 & 0.50 & 0.056 & 0.003 & 1.49 & 1.39 & 1583 & 682 \\
\hline Slovakia & $\begin{array}{l}\text { Slovak Share } \\
\text { Index }\end{array}$ & -0.05 & -0.06 & 0.25 & 0.28 & 0.049 & -0.078 & 1.30 & 1.48 & 1523 & 685 \\
\hline Slovenia & $\begin{array}{l}\text { Blue-Chip SBITOP } \\
\text { Index }\end{array}$ & 0.01 & -0.16 & 0.48 & 0.42 & 0.064 & -0.131 & 1.43 & 1.20 & 1599 & 686 \\
\hline \multicolumn{12}{|c|}{ North America } \\
\hline Canada & S\&P/TSX 60 Index & 0.09 & -0.14 & 0.55 & 0.55 & 0.042 & 0.015 & 1.73 & 1.40 & 1613 & 690 \\
\hline $\begin{array}{l}\text { United } \\
\text { States }\end{array}$ & S\&P 500 Index & 0.09 & -0.13 & 0.39 & 0.52 & 0.001 & 0.041 & 1.38 & 1.20 & 1614 & 692 \\
\hline Mexico & BOLSA Index & 0.08 & -0.14 & 0.54 & 0.57 & 0.073 & 0.050 & 1.85 & 1.52 & 1620 & 692 \\
\hline \multicolumn{12}{|c|}{ South America } \\
\hline Brazil & Bovespa Index & 0.09 & -0.22 & 0.54 & 0.57 & 0.114 & -0.036 & 2.69 & 1.97 & 1586 & 680 \\
\hline Colombia & IGBC Index & 0.06 & -0.16 & 0.49 & 0.49 & 0.131 & 0.054 & 2.02 & 1.33 & 1562 & 672 \\
\hline Chile & IPSA Index & 0.09 & -0.16 & 0.54 & 0.52 & 0.060 & 0.050 & 1.47 & 1.42 & 1598 & 690 \\
\hline Peru & $\begin{array}{l}\text { Lima General } \\
\text { Index }\end{array}$ & 0.07 & -0.09 & 0.53 & 0.37 & 0.135 & 0.061 & 1.86 & 1.61 & 1599 & 693 \\
\hline \multicolumn{12}{|c|}{ Middle-East $\mathcal{E}$ Africa } \\
\hline Egypt & EGX30 Index & 0.00 & 0.02 & 0.23 & 0.15 & 0.129 & -0.073 & 1.91 & 1.79 & 1596 & 639 \\
\hline Israel & $\begin{array}{l}\text { Tel-Aviv } 100 \\
\text { Index }\end{array}$ & 0.09 & -0.18 & 0.53 & 0.61 & 0.064 & -0.003 & 1.55 & 1.44 & 1572 & 678 \\
\hline
\end{tabular}


Table 1 (continued)

\begin{tabular}{|c|c|c|c|c|c|c|c|c|c|c|c|}
\hline \multirow[t]{2}{*}{ Country } & \multirow[t]{2}{*}{ Market index } & \multicolumn{2}{|c|}{$\rho(\mathrm{R}, \Delta \mathrm{BY} \mathrm{m})$} & \multicolumn{2}{|l|}{$\rho\left(R, R_{m}\right)$} & \multicolumn{2}{|c|}{$\begin{array}{l}\text { Daily mean return } \\
(\%)\end{array}$} & \multicolumn{2}{|c|}{$\begin{array}{l}\text { Daily standard } \\
\text { deviation (\%) }\end{array}$} & \multicolumn{2}{|l|}{ \# Obs } \\
\hline & & $\begin{array}{l}\text { Normal } \\
\text { period }\end{array}$ & $\begin{array}{l}\text { Crisis } \\
\text { period }\end{array}$ & $\begin{array}{l}\text { Normal } \\
\text { period }\end{array}$ & $\begin{array}{l}\text { Crisis } \\
\text { period }\end{array}$ & $\begin{array}{l}\text { Normal } \\
\text { period }\end{array}$ & $\begin{array}{l}\text { Crisis } \\
\text { period }\end{array}$ & $\begin{array}{l}\text { Normal } \\
\text { period }\end{array}$ & $\begin{array}{l}\text { Crisis } \\
\text { period }\end{array}$ & $\begin{array}{l}\text { Normal } \\
\text { period }\end{array}$ & $\begin{array}{l}\text { Crisis } \\
\text { period }\end{array}$ \\
\hline Morocco & $\begin{array}{l}\text { Casablanca SE } \\
\text { Index }\end{array}$ & 0.00 & -0.04 & 0.32 & 0.38 & 0.081 & -0.033 & 1.17 & 0.90 & 1559 & 694 \\
\hline South Africa & $\begin{array}{l}\text { FTSE/JSE All Share } \\
\text { Index }\end{array}$ & 0.10 & -0.18 & 0.71 & 0.64 & 0.060 & 0.032 & 2.10 & 1.77 & 1603 & 688 \\
\hline \multicolumn{12}{|c|}{ Asia: Developed } \\
\hline Australia & S\&P/ASX 200 & 0.05 & -0.01 & 0.23 & 0.26 & 0.041 & 0.010 & 1.75 & 1.61 & 1626 & 693 \\
\hline Hong Kong & Hang Seng Index & 0.05 & -0.02 & 0.24 & 0.27 & 0.045 & -0.014 & 1.76 & 1.37 & 1585 & 681 \\
\hline Japan & Nikkei 225 & 0.08 & -0.04 & 0.29 & 0.28 & 0.015 & 0.000 & 1.64 & 1.36 & 1575 & 674 \\
\hline $\begin{array}{l}\text { New } \\
\quad \text { Zealand }\end{array}$ & $\begin{array}{l}\text { NZE } 50 \text { Gross } \\
\text { Index }\end{array}$ & 0.01 & -0.01 & 0.20 & 0.24 & 0.040 & 0.032 & 1.35 & 1.12 & 1613 & 693 \\
\hline Singapore & $\begin{array}{l}\text { Straits Times } \\
\text { Index }\end{array}$ & 0.03 & -0.02 & 0.17 & 0.21 & 0.045 & 0.037 & 1.46 & 1.19 & 1610 & 691 \\
\hline \multicolumn{12}{|c|}{ Asia: Emerging } \\
\hline China & $\begin{array}{l}\text { Shanghai SE } \\
\text { Composite }\end{array}$ & 0.02 & 0.07 & 0.16 & 0.16 & 0.070 & -0.042 & 1.89 & 1.30 & 1561 & 669 \\
\hline India & BSE Sensex 30 & -0.01 & -0.02 & 0.16 & 0.12 & 0.080 & -0.013 & 2.05 & 1.49 & 1596 & 689 \\
\hline Indonesia & $\begin{array}{l}\text { Jakarta } \\
\text { Composite Index }\end{array}$ & 0.02 & -0.03 & 0.18 & 0.15 & 0.084 & 0.083 & 3.17 & 1.85 & 1547 & 678 \\
\hline Malaysia & $\begin{array}{l}\text { Kuala Lumpur } \\
\text { Composite }\end{array}$ & 0.02 & -0.02 & 0.24 & 0.28 & 0.037 & 0.053 & 1.02 & 0.90 & 1581 & 678 \\
\hline Philippine & $\begin{array}{l}\text { Philippine SE } \\
\text { Index }\end{array}$ & 0.05 & -0.05 & 0.32 & 0.32 & 0.063 & 0.108 & 1.59 & 1.28 & 1570 & 677 \\
\hline South Korea & KOSPI Index & 0.04 & -0.03 & 0.21 & 0.26 & 0.051 & 0.033 & 2.14 & 1.76 & 1594 & 686 \\
\hline Taiwan & TWSE Index & 0.03 & -0.04 & 0.24 & 0.32 & 0.020 & 0.011 & 1.53 & 1.34 & 1598 & 685 \\
\hline Thailand & SET Index & 0.04 & 0.01 & 0.20 & 0.13 & 0.027 & 0.092 & 1.59 & 1.38 & 1571 & 669 \\
\hline
\end{tabular}

This table presents the summary statistics for the sample for the normal and crisis periods. $\rho$ ( $\left.R, \Delta B Y_{m}\right)$ is the correlation between stock returns of a given market and changes in sovereign bond yields of the portfolio of crisis countries, $\rho\left(R, R_{m}\right)$ is the correlation between stock returns of a given market and the stock returns of the portfolio of crisis countries.

\section{Empirical results}

\subsection{Contagion from sovereign bond markets of crisis countries to other stock markets}

Table 2 provides the results relating to the effect of changes in sovereign bond yields of crisis countries on stock returns of other developed and emerging markets. Based on Eqs. (1) and (2), $\lambda_{1}$ measures the sensitivity of sovereign bond yield changes on stock returns, separately for normal and crisis periods. The p-values associated with normal and crisis periods show whether sovereign bond yield changes in crisis economies Granger-cause stock returns in other countries. Based on Eqs. (3) and (4), $\delta$ measures the contagion, which is the incremental impact of bond yield changes on stock returns during the crisis. One immediately striking result is that $\lambda_{1}$ is positive in normal times and negative in the crisis period. This means that changes in sovereign bond yields and stock returns are positively related during the non-crisis period and negatively correlated during the crisis period.

The positive relation between bond yield changes and stock returns during normal times reflects the typical relation between the bond market and the stock market that results from portfolio rotation from bonds to equities. When bond yields rise, bond prices decline, and investors shift from bonds to equities, increasing the demand for equities, which leads to higher stock prices and returns, leading to a positive relation between changes in bond yields and stock returns. What is more interesting is that this relation has turned negative during the eurozone debt crisis. This negative effect during the crisis can be attributed to uncertainty spillover from the sovereign bond markets of crisis countries to equity markets. During the debt crisis, sovereign bond yields rose substantially, incorporating the increase in perceived default risk of these sovereign bonds. Any default by these crisis countries was widely expected to exert a severely negative impact on the economic growth on not only the crisis and eurozone economies but also on the economies throughout the world. These negative economic effects are negative for equity markets, and the spillover of uncertainly of eurozone crisis-hit countries means lower equity prices. The result is that increases in sovereign bond yields of crisis countries during the crisis period will be associated with lower stock returns, resulting in a negative $\lambda_{1}$ as observed in the empirical results.

Now, we turn to detailed evidence for different countries, and developed and emerging markets across different regions. During the normal period, the coefficient $\lambda_{1}$ is large and significantly positive for the developed markets in Europe except for Iceland and Italy. ${ }^{8} \lambda_{1}$ is in excess of one for all markets except Iceland, and close to two for many markets. It is 1.59 for the

\footnotetext{
${ }^{8}$ The lower sensitivity of Iceland may have been caused by the Icelandic financial crisis. In order to obtain a fair picture, Iceland is excluded in estimating the average impact for developed markets.
} 
Table 2

Contagion from sovereign bond markets of crisis countries to other equity markets.

\begin{tabular}{|c|c|c|c|c|c|c|c|c|}
\hline \multirow[t]{2}{*}{ Region and type } & \multirow[t]{2}{*}{ Country } & \multicolumn{3}{|c|}{ Normal period } & \multicolumn{3}{|c|}{ Crisis period } & \multirow{2}{*}{$\begin{array}{l}\text { Contagion } \\
\delta\end{array}$} \\
\hline & & $\lambda_{1}$ & $\operatorname{Adj}-R^{2}$ & $\mathrm{p}$ & $\lambda_{1}$ & Adj-R ${ }^{2}$ & $\mathrm{p}$ & \\
\hline \multirow[t]{18}{*}{ Europe: Developed } & Austria & $1.25^{*}$ & 0.03 & 0.036 & $-1.63^{* * *}$ & 0.05 & 0.000 & $-2.90^{* * *}$ \\
\hline & Belgium & $1.44^{* *}$ & 0.02 & 0.002 & $-1.60^{* * *}$ & 0.06 & 0.000 & $-3.03^{* * *}$ \\
\hline & Denmark & $1.80^{* * *}$ & 0.02 & 0.000 & $-1.37^{* * *}$ & 0.05 & 0.000 & $-3.16^{* * *}$ \\
\hline & Finland & $1.47^{*}$ & 0.02 & 0.004 & $-1.72^{* * *}$ & 0.05 & 0.000 & $-3.18^{* * *}$ \\
\hline & France & $1.73^{* * *}$ & 0.02 & 0.000 & $-1.62^{* * *}$ & 0.05 & 0.000 & $-3.47^{* * *}$ \\
\hline & Germany & $1.42^{* * *}$ & 0.01 & 0.003 & $-1.31^{* * *}$ & 0.04 & 0.000 & $-2.78^{* * *}$ \\
\hline & Iceland & $0.29^{* *}$ & 0.02 & 0.791 & $-0.42^{* *}$ & 0.01 & 0.005 & -0.72 \\
\hline & Italy & 1.23 & 0.02 & 0.012 & $-1.79^{* * *}$ & 0.05 & 0.000 & $-3.06^{* * *}$ \\
\hline & Luxembourg & $1.25^{*}$ & 0.02 & 0.018 & $-1.35^{* * *}$ & 0.04 & 0.000 & $-2.56^{* * * *}$ \\
\hline & Netherlands & $1.87^{* * * *}$ & 0.02 & 0.000 & $-1.38^{* * *}$ & 0.05 & 0.000 & $-3.31^{* * * *}$ \\
\hline & Norway & $2.30^{* *}$ & 0.02 & 0.001 & $-1.46^{* * *}$ & 0.03 & 0.000 & $-3.77^{* * *}$ \\
\hline & Spain & $1.34^{*}$ & 0.01 & 0.006 & $-1.88^{* * *}$ & 0.07 & 0.000 & $-3.35^{* * *}$ \\
\hline & Sweden & $1.78^{* * *}$ & 0.02 & 0.002 & $-1.65^{* * *}$ & 0.04 & 0.000 & $-3.44^{* * *}$ \\
\hline & Switzerland & $0.96^{*}$ & 0.02 & 0.017 & $-0.97^{* * *}$ & 0.04 & 0.000 & $-1.95^{* * *}$ \\
\hline & United Kingdom & $1.78^{* * *}$ & 0.02 & 0.000 & $-1.12^{* * *}$ & 0.05 & 0.000 & $-2.95^{* * *}$ \\
\hline & All ex Iceland & $1.59^{* * *}$ & 0.02 & 0.002 & $-1.47^{* * *}$ & 0.06 & 0.000 & $-3.10^{* * *}$ \\
\hline & Eurozone ex crisis countries & $1.50^{* *}$ & 0.02 & 0.006 & $-1.58^{* * *}$ & 0.06 & 0.000 & $-3.12^{* * *}$ \\
\hline & Non-eurozone ex Iceland & $1.76^{* *}$ & 0.02 & 0.013 & $-1.30^{* * *}$ & 0.05 & 0.000 & $-3.09^{* * *}$ \\
\hline \multirow[t]{6}{*}{ Europe: Emerging } & Czech Republic & 0.95 & 0.03 & 0.123 & $-1.43^{* *}$ & 0.05 & 0.000 & $-2.42^{* *}$ \\
\hline & Hungary & $1.76^{* * *}$ & 0.03 & 0.013 & $-2.24^{* * *}$ & 0.06 & 0.000 & $-3.92^{* *}$ \\
\hline & Poland & $1.50^{*}$ & 0.03 & 0.010 & $-1.56^{* *}$ & 0.04 & 0.000 & $-2.99^{* * *}$ \\
\hline & Russia & $2.59^{* *}$ & 0.01 & 0.003 & $-1.10^{* * *}$ & 0.02 & 0.000 & $-3.74^{* * *}$ \\
\hline & Turkey & $2.65^{* * * *}$ & 0.02 & 0.001 & $-1.12^{* *}$ & 0.02 & 0.000 & $-3.76^{* * *}$ \\
\hline & All & $2.02^{* *}$ & 0.03 & 0.001 & $-1.53^{* *}$ & 0.05 & 0.000 & $-3.52^{* * *}$ \\
\hline \multirow[t]{5}{*}{ Eurozone: Frontier } & Estonia & -0.23 & 0.05 & 0.522 & $-1.03^{* *}$ & 0.03 & 0.000 & -0.78 \\
\hline & Malta & 0.15 & 0.05 & 0.868 & $-0.69^{* *}$ & 0.03 & 0.001 & -0.84 \\
\hline & Slovakia & $-0.78^{* * * *}$ & 0.02 & 0.034 & $-0.33^{*}$ & 0.00 & 0.101 & 0.46 \\
\hline & Slovenia & 0.19 & 0.07 & 0.783 & $-0.78^{* * *}$ & 0.05 & 0.000 & $-0.95^{*}$ \\
\hline & All & -0.19 & 0.05 & 0.428 & $-0.70^{* *}$ & 0.05 & 0.000 & -0.53 \\
\hline \multirow[t]{2}{*}{ Eurozone } & Eurozone & 0.94 & 0.03 & 0.019 & $-1.44^{* * * *}$ & 0.08 & 0.000 & $-2.41^{* * * *}$ \\
\hline & Eurozone Core & $1.56^{* *}$ & 0.02 & 0.001 & $-1.51^{* * *}$ & 0.06 & 0.000 & $-3.10^{* * *}$ \\
\hline \multirow[t]{4}{*}{ North America } & Canada & $1.84^{* * *}$ & 0.02 & 0.000 & $-0.72^{* * *}$ & 0.02 & 0.000 & $-2.60^{* * * *}$ \\
\hline & United States & $1.41^{* * * *}$ & 0.05 & 0.000 & $-0.63^{* * *}$ & 0.02 & 0.000 & $-2.08^{* * *}$ \\
\hline & Mexico & $2.00^{* * * *}$ & 0.04 & 0.000 & $-0.76^{* * *}$ & 0.02 & 0.000 & $-2.71^{* * *}$ \\
\hline & All & $1.55^{* * *}$ & 0.03 & 0.000 & $-0.60^{* * * *}$ & 0.02 & 0.000 & $-2.18^{* * *}$ \\
\hline \multirow[t]{5}{*}{ South America } & Brazil & $3.28^{\text {*** }}$ & 0.01 & 0.000 & $-1.53^{* * *}$ & 0.05 & 0.000 & $-4.83^{* * *}$ \\
\hline & Chile & $1.61^{* * * *}$ & 0.02 & 0.000 & $-0.80^{* * * *}$ & 0.05 & 0.000 & $-2.43^{* * *}$ \\
\hline & Colombia & $1.59^{* *}$ & 0.02 & 0.010 & $-0.75^{* * *}$ & 0.03 & 0.000 & $-2.34^{* * *}$ \\
\hline & Peru & $1.79^{* *}$ & 0.06 & 0.001 & $-0.54^{* *}$ & 0.01 & 0.018 & $-2.29^{* * *}$ \\
\hline & All & $2.10^{* * *}$ & 0.03 & 0.000 & $-0.92^{* * *}$ & 0.05 & 0.000 & $-3.02^{* * *}$ \\
\hline Middle-East \& Africa: Developed & Israel & $1.22^{*}$ & 0.01 & 0.001 & $-0.74^{* *}$ & 0.03 & 0.000 & $-1.96^{* * *}$ \\
\hline \multirow[t]{4}{*}{ Middle-East \& Africa: Emerging } & Egypt & 0.10 & 0.06 & 0.982 & 0.21 & 0.05 & 0.938 & 0.19 \\
\hline & Morocco & 0.06 & 0.07 & 0.940 & -0.09 & 0.02 & 0.487 & -0.13 \\
\hline & South Africa & $2.52^{* * *}$ & 0.01 & 0.000 & $-1.22^{* * *}$ & 0.04 & 0.000 & $-3.75^{* * *}$ \\
\hline & All & $0.87^{* *}$ & 0.05 & 0.002 & -0.27 & 0.01 & 0.001 & $-1.11^{* *}$ \\
\hline \multirow[t]{6}{*}{ Asia: Developed } & Australia & $1.08^{*}$ & 0.01 & 0.044 & 0.13 & 0.01 & 0.618 & $-1.10^{*}$ \\
\hline & Hong Kong & $1.02^{*}$ & 0.01 & 0.050 & -0.09 & 0.00 & 0.637 & $-1.14^{* *}$ \\
\hline & Japan & $1.44^{* * *}$ & 0.03 & 0.005 & -0.28 & 0.12 & 0.120 & $-1.75^{* * * *}$ \\
\hline & New Zealand & 0.19 & 0.02 & 0.705 & 0.11 & 0.02 & 0.614 & -0.16 \\
\hline & Singapore & 0.55 & 0.01 & 0.190 & 0.02 & 0.00 & 0.935 & -0.58 \\
\hline & All & $0.84^{*}$ & 0.02 & 0.032 & 0.03 & 0.01 & 0.901 & $-0.87^{*}$ \\
\hline \multirow[t]{6}{*}{ Asia: Emerging } & China & 0.55 & 0.00 & 0.355 & $0.33^{* * *}$ & 0.00 & 0.082 & -0.20 \\
\hline & India & -0.27 & 0.02 & 0.734 & -0.13 & 0.00 & 0.620 & -0.14 \\
\hline & Indonesia & 0.79 & 0.03 & 0.342 & $-0.41^{*}$ & 0.01 & 0.135 & $-1.21^{*}$ \\
\hline & Malaysia & 0.16 & 0.02 & 0.614 & -0.00 & 0.01 & 0.827 & -0.16 \\
\hline & Philippines & $0.95^{* *}$ & 0.02 & 0.050 & -0.15 & 0.01 & 0.420 & $-1.09^{* * * *}$ \\
\hline & South Korea & 0.99 & 0.01 & 0.107 & -0.22 & 0.00 & 0.371 & $-1.28^{*}$ \\
\hline
\end{tabular}


Table 2 (continued)

\begin{tabular}{|c|c|c|c|c|c|c|c|c|}
\hline \multirow[t]{2}{*}{ Region and type } & \multirow[t]{2}{*}{ Country } & \multicolumn{3}{|c|}{ Normal period } & \multicolumn{3}{|c|}{ Crisis period } & \multirow{2}{*}{$\begin{array}{l}\text { Contagion } \\
\delta \\
\end{array}$} \\
\hline & & $\lambda_{1}$ & Adj-R ${ }^{2}$ & $\mathrm{p}$ & $\lambda_{1}$ & Adj-R ${ }^{2}$ & $\mathrm{p}$ & \\
\hline & Taiwan & 0.68 & 0.01 & 0.177 & -0.13 & 0.00 & 0.454 & $-0.82^{*}$ \\
\hline & Thailand & $0.87^{* * *}$ & 0.01 & 0.085 & 0.08 & 0.00 & 0.792 & $-0.81^{*}$ \\
\hline & All & 0.53 & 0.04 & 0.155 & -0.10 & 0.01 & 0.535 & -0.61 \\
\hline
\end{tabular}

This table reports the results relating to the impact of changes in sovereign bond yields of crisis countries on other overlapping (Eqs. (1) and (3)) and nonoverlapping equity markets (Eqs. (2) and (4)).

$\mathrm{R}_{\mathrm{t}}=\alpha+\sum_{\mathrm{j}=1}^{2} \beta_{\mathrm{j}}\left(\mathrm{R}_{\mathrm{t}-\mathrm{j}}\right)+\lambda_{1}\left(\mathrm{X}_{\mathrm{t}}\right)+\lambda_{2}\left(\mathrm{X}_{\mathrm{t}-1}\right)+\mu\left(\mathrm{DUS}_{\mathrm{t}}\right)+\varepsilon_{\mathrm{t}}(1)$

$\mathrm{R}_{\mathrm{t}}=\alpha+\sum_{\mathrm{j}=1}^{2} \beta_{\mathrm{j}}\left(\mathrm{R}_{\mathrm{t}-\mathrm{j}}\right)+\lambda_{1}\left(\mathrm{X}_{\mathrm{t}-1}\right)+\lambda_{2}\left(\mathrm{X}_{\mathrm{t}-2}\right)+\mu\left(\mathrm{DUS}_{\mathrm{t}}\right)+\varepsilon_{\mathrm{t}}(2)$

$\mathrm{R}_{\mathrm{t}}=\alpha+\sum_{\mathrm{j}=1}^{2} \beta_{\mathrm{j}}\left(\mathrm{R}_{\mathrm{t}-\mathrm{j}}\right)+\lambda_{1}\left(\mathrm{X}_{\mathrm{t}}\right)+\lambda_{2}\left(\mathrm{X}_{\mathrm{t}-1}\right)+\mu\left(\mathrm{DUS}_{\mathrm{t}}\right)+\delta\left(\mathrm{X}_{\mathrm{t}} * \mathrm{DEZ}\right)+\varepsilon_{\mathrm{t}}(3)$

$\mathrm{R}_{\mathrm{t}}=\alpha+\sum_{\mathrm{j}=1}^{2} \beta_{\mathrm{j}}\left(\mathrm{R}_{\mathrm{t}-\mathrm{j}}\right)+\lambda_{1}\left(\mathrm{X}_{\mathrm{t}-1}\right)+\lambda_{2}\left(\mathrm{X}_{\mathrm{t}-2}\right)+\mu\left(\mathrm{DUS}_{\mathrm{t}}\right)+\delta\left(\mathrm{X}_{\mathrm{t}-1} * \mathrm{DEZ}\right)+\varepsilon_{\mathrm{t}}(4)$

$R_{t}$ is the stock return of a given national equity market. $\mathrm{X}$ is change in average bond yield of crisis countries, $\Delta \mathrm{BY} \mathrm{M}_{\mathrm{M}}$. DUS is the U.S. subprime crisis dummy that takes the value of one during the period from $9 / 01 / 2008$ to $03 / 09 / 2009$ and zero otherwise. The subscript $t$ represents the trading day. $\alpha$ is the intercept, and $\varepsilon_{t}$ is the error term of the regressions. The table shows the estimates of $\lambda_{1}$, the adjusted $\mathrm{R}^{2}$, the p-values for tests of Granger causality, and the contagion coefficient $\delta$. The total sample period is from $11 / 01 / 2003$ to $12 / 31 / 2012$, and the crisis period is from $11 / 2009$ to $07 / 2012$.

**** Significant at $1 \%$.

*** Significant at $5 \%$.

Significant at $10 \%$

European developed markets as a whole excluding Iceland suggesting that a $1 \%$ increase in the average sovereign bond yield of crisis countries is associated with a $1.59 \%$ increase in stock returns. The developed markets in the eurozone have experienced an effect of similar magnitude. However, many of the larger effects are associated with developed markets such as Denmark, Norway, Sweden, and the UK, which are not part of the eurozone, resulting in an average $\lambda_{1}$ of 1.76 for non-eurozone developed markets in Europe. Thus, sovereign bond yield changes of crisis countries seem to impact non-eurozone developed countries in Europe much more than eurozone developed countries during normal periods. The Granger-causality tests, as reflected in p-values, confirm that, except for Iceland, bond yield changes indeed add significantly to explaining the behavior of stock returns in European developed markets during normal times.

The results for the crisis period show a large and significant negative effect of sovereign bond yield changes with an average of -1.47 for developed markets in Europe. This is a remarkable reversal from the large positive effect observed during normal times. As pointed out earlier, what this means is that the relation between bond yield changes and stock returns turned negative during the debt crisis providing strong evidence of spillover of economic uncertainty from crisis countries to equity markets. The p-values confirm that stock returns in all European developed markets are Granger-caused by bond yield changes during the debt crisis.

There is similar evidence of a positive $\lambda_{1}$ during the normal period, except for the Czech Republic, and a negative $\lambda_{1}$ during the crisis period for emerging markets in Europe. Out of the four frontier markets that are in the eurozone, only Slovakia shows a reliable effect during normal times. But, unlike other markets, this effect is negative. In contrast, even these frontier markets show a reliable negative relation between sovereign yield changes and stock returns during the crisis period. Further, the results show reliable evidence of stock returns in all European emerging and frontier markets, except for Slovakia, being Granger-caused by sovereign bond yield changes during the debt crisis.

The North American stock markets, i.e., Canada, USA, and Mexico, also respond to sovereign bond yield changes of crisis countries reliably positively during normal times and reliably negatively during the crisis period. Mexico exhibits the highest sensitivity with $\lambda_{1}$ of 2.00 . However, the $\lambda_{1}$ coefficients during the crisis period are much smaller and about less than half in magnitude to those observed in the European markets. For instance, the sensitivity of U.S. stock returns to changes in sovereign bond yields is -0.63 during the crisis period. Yet, this is a large decrease from a positive coefficient of 1.41 observed during normal times. There is also strong evidence that sovereign bond yield changes Granger-cause stock returns in the North American markets both during normal and crisis times.

The South American emerging stock markets also exhibit a very high level of sensitivity to sovereign bond yield changes of crisis nations during the normal period with the most sensitive market being Brazil with $\lambda_{1}$ equal to 3.28 and reliable at $1 \%$ significance level. During the debt crisis, the South American markets provide reliable evidence of sovereign bond yields changes of crisis countries negatively affecting their stock markets. Although the magnitude of such effects are smaller than those observed in European markets, they are higher than the magnitude found in North America, and represent a large change from the positive effects observed during the normal period. In the Middle-East and Africa region, only Israel and South Africa provide evidence of a strong positive effect during normal times and a strong negative effect during crisis times. The p-values provide reliable evidence that sovereign bond yield changes Granger-cause stock returns in all South American markets, and in Israel and South Africa during both normal and crisis periods.

The markets in Asia, however, portray a different picture. While the relation between sovereign yield changes and stock returns during the normal period is positive in all Asian markets, expect India where it is insignificantly negative, such evidence is not widespread. The positive effect is strong for Japan, the Philippines, and Thailand whereas it is weakly significant 
for Australia and Hong Kong. Similarly, while there is a negative effect of sovereign yield changes for most Asian markets during the period of the debt crisis, none is significant with the exception of Indonesia, which is significant at $10 \%$. The Chinese stock market, in contrast, responds significantly positively to sovereign yield changes during the crisis. Overall, there is very little evidence, if any, of sovereign bond yield changes affecting the Asian stock markets during either normal or crisis times. The p-values associated with Granger-causality tests further confirm this conclusion. During normal times, changes in sovereign bond yields of crisis countries Granger-cause stock returns in Australia, Hong Kong, Japan, the Philippines and Thailand only. In Asian markets during the eurozone debt crisis, only Chinese stock returns are Granger-caused by sovereign yield changes.

In sum, changes in sovereign bond yields of crisis countries have had a large negative impact on equity markets around the world during the eurozone crisis. Put it differently, there is evidence of "negative contagion" from sovereign bond markets to stock markets, except in Asia where such evidence is weak and sparse. This overall evidence is consistent with spillover of economic uncertainty from crisis countries to equity markets. This evidence is also consistent with the "risk-on riskoff hypothesis" where investors tend to engage in high-risk investments when risk is perceived as low and exit from such investments when risk is perceived as high.

\subsection{Contagion from stock markets of crisis countries to other stock markets}

Table 3 reports the estimates of the impact of stock returns of crisis countries on other stock markets around the world. $\lambda_{1}$ captures the influence of stock returns of the portfolio of crisis countries on other equity markets, based on Eqs. (1) and (2). In effect, the portfolio of crisis countries acts like the market portfolio, and the $\lambda_{1}$ coefficients correspond to market beta of each stock market relative to the portfolio of crisis markets. The p-values associated with normal and crisis periods show whether stock returns of crisis countries Granger-cause stock returns in other markets. $\delta$ is the contagion coefficient which measures the incremental impact of stock returns of crisis countries on stock returns of other countries during the crisis, based on Eqs. (3) and (4).

Two things are immediately clear. First, as expected, market betas are positive and significant at $1 \%$ for all markets both during the normal period and the crisis period, with the exception of Iceland for which the beta is not significant during the normal period. Second, the market betas are significantly lower during the crisis period. Taken together, these two results suggest that while stock markets around the world are significantly positively affected by stock market performance of crisis countries during relatively tranquil times, such impact has in fact declined during the period of the eurozone debt crisis. This is a very interesting result because prior studies have largely found increases in cross-market linkages during crises (For example, King and Wadhwani (1990), Lee and Kim (1993), and Karolyi and Stulz (1996)). Hence, one would have expected to find that equity markets around the world become more sensitive to the eurozone debt crisis. But indeed the empirical results of this paper clearly show reliable evidence that stock markets have become less sensitive to the eurozone crisis, suggesting evidence of some sort of decoupling of world equity markets from the performance of equity markets in the crisis countries.

During the normal period, as one would expect, the market betas are very high for the European equity markets, both developed and emerging. It is 0.85 for Europe's developed markets and 0.99 for Europe's emerging markets, indicating that emerging stocks markets are more sensitive to stock markets in crisis economies in normal times. Market betas during the crisis periods are much lower. For Europe's developed markets, it is 0.65 , which represents a 25 point drop from pre-crisis beta. For non-eurozone developed markets, the market beta is 0.58 , which represents a 27-point drop. The decline is beta during the crisis period is even larger for Europe's emerging markets which have an average beta of just 0.68 pointing to a drop of 31 points. The eurozone frontier markets are much less sensitive to the stock markets in crisis countries during the normal period as evidenced by a market beta is 0.39 , which is about half of the market beta for developed markets. They also have experienced about an 8-point decline in market beta.

On average, the equity market beta of the North American markets relative to crisis economies is 0.50 during normal times. However, this lower sensitivity is largely due the lower beta of 0.45 for the U.S., and Canada and Mexico each has a higher sensitivity of about 0.65 . The market beta of North American markets has also declined to 0.34 during the crisis. The sensitivity of the South American emerging markets during the normal period is higher, i.e. 0.70, in line with Canada and Mexico, and such betas also have experienced proportionately larger declines during the crisis. Similarly, betas have declined significantly in the Middle-East and African markets. Thus, there is reliable evidence that the emerging markets in Europe, South America, the Middle-East and Africa have experienced the largest declines in their equity market betas during the eurozone debt crisis.

Turning to the results for the Asian region, it is very clear that the Asian markets have the lowest sensitivity to the crisis economies both during the normal and crisis periods. The average market beta is 0.33 for Asian developed markets, and New Zealand and Singapore stand out with their very low sensitivity of 0.19 . The decoupling of the Asian developed markets during the crisis is very dramatic. With an average market beta of just 0.19 during the crisis, these markets have become fairly immune from the equity market volatilities in crisis-hit economies. Interestingly, the average market beta for the Asian emerging markets is 0.25 during the normal period, even lower than that for the Asian developed markets. This suggests that the Asian emerging markets have experienced the least sensitivity to the equity markets in crisis countries. As a point of similarity, Bekaert et al. (2005) report no meaningful contagion in Asia during the Asian crisis. 
Table 3

Contagion from equity markets of crisis countries to other equity markets.

\begin{tabular}{|c|c|c|c|c|c|c|c|c|}
\hline \multirow[t]{2}{*}{ Region and type } & \multirow[t]{2}{*}{ Country } & \multicolumn{3}{|c|}{ Normal period } & \multicolumn{3}{|c|}{ Crisis period } & \multirow{2}{*}{$\begin{array}{l}\text { Contagion } \\
\delta\end{array}$} \\
\hline & & $\lambda_{1}$ & Adj-R ${ }^{2}$ & $\mathrm{p}$ & $\lambda_{1}$ & Adj-R ${ }^{2}$ & $\mathrm{p}$ & \\
\hline \multirow[t]{18}{*}{ Europe: Developed } & Austria & $0.97^{* * * *}$ & 0.62 & 0.000 & $0.73^{* * * *}$ & 0.53 & 0.000 & $-0.24^{* * *}$ \\
\hline & Belgium & $0.78^{* * * *}$ & 0.62 & 0.000 & $0.66^{* * *}$ & 0.55 & 0.000 & $-0.11^{* *}$ \\
\hline & Denmark & $0.81^{* * * *}$ & 0.58 & 0.000 & $0.56^{* * *}$ & 0.48 & 0.000 & $-0.24^{* * *}$ \\
\hline & Finland & $0.88^{\text {***** }}$ & 0.62 & 0.000 & $0.71^{* * * *}$ & 0.49 & 0.000 & $-0.16^{* * *}$ \\
\hline & France & $0.87^{* * * *}$ & 0.64 & 0.000 & $0.74^{* * * *}$ & 0.54 & 0.000 & $-0.12^{* *}$ \\
\hline & Germany & $0.81^{* * * *}$ & 0.58 & 0.000 & $0.67^{* * *}$ & 0.51 & 0.000 & $-0.13^{* *}$ \\
\hline & Iceland & 0.16 & 0.04 & 0.003 & $0.20^{* * * *}$ & 0.15 & 0.000 & 0.02 \\
\hline & Italy & $0.84^{* * * *}$ & 0.63 & 0.000 & $0.79^{* * *}$ & 0.52 & 0.000 & -0.05 \\
\hline & Luxembourg & $0.77^{* * * *}$ & 0.53 & 0.000 & $0.55^{* * *}$ & 0.44 & 0.000 & $-0.22^{* * *}$ \\
\hline & Netherlands & $0.86^{* * * *}$ & 0.63 & 0.000 & $0.62^{* * * *}$ & 0.54 & 0.000 & $-0.24^{* * *}$ \\
\hline & Norway & $1.06^{* * * *}$ & 0.49 & 0.000 & $0.72^{* * *}$ & 0.46 & 0.000 & $-0.34^{* * * *}$ \\
\hline & Spain & $0.86^{* * * *}$ & 0.63 & 0.000 & $0.79^{* * * *}$ & 0.51 & 0.000 & -0.05 \\
\hline & Sweden & $0.96^{* * * *}$ & 0.56 & 0.000 & $0.70^{* * *}$ & 0.45 & 0.000 & $-0.26^{* * *}$ \\
\hline & Switzerland & $0.65^{* * *}$ & 0.56 & 0.000 & $0.42^{* * * *}$ & 0.41 & 0.000 & $-0.23^{* * *}$ \\
\hline & United Kingdom & $0.78^{* * * *}$ & 0.60 & 0.000 & $0.50^{* * * *}$ & 0.45 & 0.000 & $-0.28^{* * *}$ \\
\hline & All ex Iceland & $0.85^{* * * *}$ & 0.70 & 0.000 & $0.65^{* * * *}$ & 0.56 & 0.000 & $-0.19^{* * *}$ \\
\hline & Eurozone ex crisis countries & $0.85^{* * * * *}$ & 0.70 & 0.000 & $0.70^{* * *}$ & 0.57 & 0.000 & $-0.14^{* * *}$ \\
\hline & Non-eurozone ex Iceland & $0.85^{* * *}$ & 0.66 & 0.000 & $0.58^{* * *}$ & 0.51 & 0.000 & $-0.27^{* * *}$ \\
\hline \multirow[t]{6}{*}{ Europe: Emerging } & Czech Republic & $0.96^{* * * *}$ & 0.52 & 0.000 & $0.66^{* * * *}$ & 0.51 & 0.000 & $-0.30^{* * *}$ \\
\hline & Hungary & $0.95^{* * *}$ & 0.41 & 0.000 & $0.84^{* * * *}$ & 0.42 & 0.000 & $-0.11^{*}$ \\
\hline & Poland & $0.90^{* * * *}$ & 0.49 & 0.000 & $0.71^{* * *}$ & 0.48 & 0.000 & $-0.06^{* *}$ \\
\hline & Russia & $1.10^{* * * *}$ & 0.35 & 0.000 & $0.63^{* * *}$ & 0.36 & 0.000 & $-0.47^{* * * *}$ \\
\hline & Turkey & $1.04^{* * * *}$ & 0.35 & 0.000 & $0.56^{* * *}$ & 0.32 & 0.000 & $-0.47^{* * *}$ \\
\hline & All & $0.99^{* * * *}$ & 0.58 & 0.000 & $0.68^{* * *}$ & 0.54 & 0.000 & $-0.30^{* * *}$ \\
\hline \multirow[t]{5}{*}{ Eurozone Frontier Markets } & Estonia & $0.46^{* * * *}$ & 0.29 & 0.000 & $0.41^{* * *}$ & 0.26 & 0.000 & -0.04 \\
\hline & Malta & $0.46^{* * *}$ & 0.29 & 0.000 & $0.35^{* * *}$ & 0.26 & 0.000 & $-0.12^{* * *}$ \\
\hline & Slovakia & $0.20^{* * *}$ & 0.07 & 0.000 & $0.21^{* * *}$ & 0.08 & 0.000 & 0.01 \\
\hline & Slovenia & $0.42^{* * * *}$ & 0.29 & 0.000 & $0.24^{* * *}$ & 0.19 & 0.000 & $-0.18^{* * *}$ \\
\hline & All & $0.39^{* * *}$ & 0.37 & 0.000 & $0.31^{* * *}$ & 0.34 & 0.000 & $-0.08^{* * *}$ \\
\hline \multirow[t]{2}{*}{ Eurozone } & Eurozone & $0.77^{\text {***** }}$ & 0.83 & 0.000 & $0.68^{* * *}$ & 0.76 & 0.000 & $-0.09^{* * *}$ \\
\hline & Eurozone Core & $0.85^{* * * *}$ & 0.70 & 0.000 & $0.67^{* * *}$ & 0.56 & 0.000 & $-0.17^{* * *}$ \\
\hline \multirow[t]{4}{*}{ North America } & Canada & $0.64^{* * * *}$ & 0.32 & 0.000 & $0.39^{* * *}$ & 0.30 & 0.000 & $-0.25^{* * *}$ \\
\hline & United States & $0.45^{* * * *}$ & 0.26 & 0.000 & $0.33^{* * *}$ & 0.30 & 0.000 & $-0.11^{* *}$ \\
\hline & Mexico & $0.65^{* * *}$ & 0.30 & 0.000 & $0.44^{* * *}$ & 0.33 & 0.000 & $-0.21^{* * * *}$ \\
\hline & All & $0.50^{* * *}$ & 0.31 & 0.000 & $0.34^{* * *}$ & 0.32 & 0.000 & $-0.15^{* * *}$ \\
\hline \multirow[t]{5}{*}{ South America } & Brazil & $0.97^{* * *}$ & 0.30 & 0.000 & $0.57^{* * *}$ & 0.32 & 0.000 & $-0.39^{* * *}$ \\
\hline & Chile & $0.53^{* * * *}$ & 0.30 & 0.000 & $0.38^{* * *}$ & 0.29 & 0.000 & $-0.14^{* * *}$ \\
\hline & Colombia & $0.66^{* * * *}$ & 0.25 & 0.000 & $0.33^{* * *}$ & 0.25 & 0.000 & $-0.32^{* * *}$ \\
\hline & Peru & $0.62^{* \text { **** }}$ & 0.31 & 0.000 & $0.31^{* * *}$ & 0.14 & 0.000 & $-0.32^{* * *}$ \\
\hline & All & $0.70^{* * *}$ & 0.41 & 0.000 & $0.40^{* * *}$ & 0.35 & 0.000 & $-0.30^{* * *}$ \\
\hline Middle-East \& Africa: Developed & Israel & $0.56^{\text {***** }}$ & 0.30 & 0.000 & $0.43^{* * *}$ & 0.39 & 0.000 & $-012^{* *}$ \\
\hline \multirow[t]{4}{*}{ Middle-East \& Africa: Emerging } & Egypt & $0.22^{* * * *}$ & 0.15 & 0.000 & $0.17^{\text {**** }}$ & 0.08 & 0.000 & -0.10 \\
\hline & Morocco & $0.23^{* * *}$ & 0.16 & 0.000 & $0.17^{* * *}$ & 0.16 & 0.000 & $-0.06^{* *}$ \\
\hline & South Africa & $0.97^{* * * *}$ & 0.50 & 0.000 & $0.57^{* * *}$ & 0.41 & 0.000 & $-0.39^{* * *}$ \\
\hline & All & $0.51^{* * * *}$ & 0.40 & 0.000 & $0.32^{* * *}$ & 0.32 & 0.000 & $-0.19^{* * *}$ \\
\hline \multirow[t]{6}{*}{ Asia: Developed } & Australia & $0.41^{* * * *}$ & 0.08 & 0.000 & $0.21^{* * *}$ & 0.06 & 0.000 & -0.08 \\
\hline & Hong Kong & $0.37^{* * * *}$ & 0.09 & 0.000 & $0.21^{* * * *}$ & 0.08 & 0.000 & $-0.13^{* *}$ \\
\hline & Japan & $0.41^{* * * *}$ & 0.15 & 0.000 & $0.21^{* * * *}$ & 0.12 & 0.000 & $-0.18^{* * *}$ \\
\hline & New Zealand & $0.19^{* * * *}$ & 0.05 & 0.000 & $0.13^{* * *}$ & 0.06 & 0.000 & -0.03 \\
\hline & Singapore & $0.19^{* * * *}$ & 0.04 & 0.000 & $0.14^{* * *}$ & 0.04 & 0.000 & -0.03 \\
\hline & All & $0.33^{\text {**** }}$ & 0.11 & 0.000 & $0.19^{* * *}$ & 0.10 & 0.000 & $-0.10^{* *}$ \\
\hline \multirow[t]{6}{*}{ Asia: Emerging } & China & $0.21^{* * * *}$ & 0.03 & 0.000 & $0.11^{* * * *}$ & 0.03 & 0.000 & $-0.09^{*}$ \\
\hline & India & $0.19^{\text {**** }}$ & 0.04 & 0.000 & $0.11^{* * *}$ & 0.02 & 0.000 & $-0.11^{*}$ \\
\hline & Indonesia & $0.46^{* * * * *}$ & 0.09 & 0.000 & $0.21^{* * * *}$ & 0.07 & 0.000 & $-0.26^{* * *}$ \\
\hline & Malaysia & $0.14^{* * * *}$ & 0.06 & 0.000 & $0.13^{* * *}$ & 0.08 & 0.000 & -0.03 \\
\hline & Philippines & $0.32^{* * * *}$ & 0.10 & 0.000 & $0.21^{* * *}$ & 0.10 & 0.000 & $-0.11^{* *}$ \\
\hline & South Korea & $0.35^{\text {**** }}$ & 0.06 & 0.000 & $0.28^{* * *}$ & 0.09 & 0.000 & -0.08 \\
\hline
\end{tabular}


Table 3 (continued)

\begin{tabular}{|c|c|c|c|c|c|c|c|c|}
\hline \multirow[t]{2}{*}{ Region and type } & \multirow[t]{2}{*}{ Country } & \multicolumn{3}{|c|}{ Normal period } & \multicolumn{3}{|c|}{ Crisis period } & \multirow{2}{*}{$\begin{array}{l}\text { Contagion } \\
\delta\end{array}$} \\
\hline & & $\lambda_{1}$ & Adj-R ${ }^{2}$ & $\mathrm{p}$ & $\lambda_{1}$ & Adj-R ${ }^{2}$ & $\mathrm{p}$ & \\
\hline & Taiwan & $0.25^{* * * *}$ & 0.06 & 0.000 & $0.23^{* * *}$ & 0.11 & 0.000 & -0.02 \\
\hline & Thailand & $0.21^{* * * *}$ & 0.05 & 0.000 & $0.09^{* * *}$ & 0.01 & 0.000 & $-0.12^{* * *}$ \\
\hline & All & $0.25^{\text {**** }}$ & 0.10 & 0.000 & $0.18^{* * * *}$ & 0.09 & 0.000 & $-0.09^{* *}$ \\
\hline
\end{tabular}

This table reports the results relating to the impact of stock returns of crisis countries on other overlapping (Eqs. (1) and (3)) and non-overlapping equity markets (Eqs. (2) and (4)).

$\mathrm{R}_{\mathrm{t}}=\alpha+\sum_{\mathrm{j}=1}^{2} \beta_{\mathrm{j}}\left(\mathrm{R}_{\mathrm{t}-\mathrm{j}}\right)+\lambda_{1}\left(\mathrm{X}_{\mathrm{t}}\right)+\lambda_{2}\left(\mathrm{X}_{\mathrm{t}-1}\right)+\mu\left(\mathrm{DUS}_{\mathrm{t}}\right)+\varepsilon_{\mathrm{t}}(1)$

$\mathrm{R}_{\mathrm{t}}=\alpha+\sum_{\mathrm{j}=1}^{2} \beta_{\mathrm{j}}\left(\mathrm{R}_{\mathrm{t}-\mathrm{j}}\right)+\lambda_{1}\left(\mathrm{X}_{\mathrm{t}-1}\right)+\lambda_{2}\left(\mathrm{X}_{\mathrm{t}-2}\right)+\mu\left(\mathrm{DUS}_{\mathrm{t}}\right)+\varepsilon_{\mathrm{t}}(2)$

$\mathrm{R}_{\mathrm{t}}=\alpha+\sum_{\mathrm{j}=1}^{2} \beta_{\mathrm{j}}\left(\mathrm{R}_{\mathrm{t}-\mathrm{j}}\right)+\lambda_{1}\left(\mathrm{X}_{\mathrm{t}}\right)+\lambda_{2}\left(\mathrm{X}_{\mathrm{t}-1}\right)+\mu\left(\mathrm{DUS}_{\mathrm{t}}\right)+\delta\left(\mathrm{X}_{\mathrm{t}} * \mathrm{DEZ}\right)+\varepsilon_{\mathrm{t}}(3)$

$\mathrm{R}_{\mathrm{t}}=\alpha+\sum_{\mathrm{j}=1}^{2} \beta_{\mathrm{j}}\left(\mathrm{R}_{\mathrm{t}-\mathrm{j}}\right)+\lambda_{1}\left(\mathrm{X}_{\mathrm{t}-1}\right)+\lambda_{2}\left(\mathrm{X}_{\mathrm{t}-2}\right)+\mu\left(\mathrm{DUS}_{\mathrm{t}}\right)+\delta\left(\mathrm{X}_{\mathrm{t}-1} * \mathrm{DEZ}\right)+\varepsilon_{\mathrm{t}}(4)$

$R_{t}$ is the stock return of a given national equity market. X is average stock returns of crisis countries, R $\mathrm{M}_{\mathrm{m}, \mathrm{t}}$. DUS is the U.S. subprime crisis dummy that takes the value of one during the period from $9 / 01 / 2008$ to $03 / 09 / 2009$ and zero otherwise. The subscript $t$ represents the trading day. $\alpha$ is the intercept, and $\varepsilon_{t}$ is the error term of the regressions. The table shows the estimates of $\lambda_{1}$, the adjusted $\mathrm{R}^{2}$, the p-values for tests of Granger causality, and the contagion coefficient $\delta$. The total sample period is from $11 / 01 / 2003$ to $12 / 31 / 2012$, and the crisis period is from $11 / 2009$ to $07 / 2012$.

**** Significant at $1 \%$.

** Significant at $5 \%$.

* Significant at $10 \%$.

These results for Asian markets extraordinarily contrast with the earlier finding that emerging markets in the other regions of the world have the largest sensitivity to stock markets in crisis countries. During the crisis period, just like all other evidence discussed so far, the Asian emerging markets' stock betas declined to an average of 0.18 , making them the least sensitive to the crisis economies during the eurozone crisis. It must be pointed out that, with a market beta of just 0.11 during the crisis, China and India stand out as the stock markets that are most immune from the eurozone crisis among the big emerging markets. This contrasts with market beta of 0.57 for Brazil and 0.63 for Russia, the other two BRIC nations, during the crisis.

Overall, there is strong pervasive evidence of positive sensitivity of stock markets around world to the stock markets in crisis countries both during normal and crisis periods. The p-values associated with Granger causality tests confirm that indeed stock returns in other markets are Granger-caused by stock returns in crisis economies. The most important is the finding that during the crisis this sensitivity turned less positive. As a result, the incremental change in the sensitivity during the crisis is negative as shown by reliable contagion coefficients, $\delta$. The contagion is large and negative in European, North and South American, the Middle-Eastern, and African equity markets. While there is negative contagion in Asia as well, the magnitude of contagion is much lower, and the evidence is not widespread across markets.

Finally, the above results also shed some light on the decoupling hypothesis. During normal times, stock markets around the world are coupled with the stock markets in crisis countries, as evidenced by large and positive sensitivities. However, during the eurozone crisis, the preponderance of evidence suggests that equity markets around the world became less sensitivity to the eurozone crisis, as clearly captured by negative contagion coefficients, suggesting evidence of decoupling during the crisis. The results are robust to alternative model and variable specifications. ${ }^{9}$

\subsection{Policy implications}

The findings of this study have important implications for both investors and policy makers. It is clear that during times of a debt crisis, both bond markets and stock markets in crisis-hit countries function as important transmission mechanisms of negative information to stock markets around the world. The relation between bond markets of crisis countries and stock markets of the rest of world is positive during normal times and turns negative during the crisis, whereas the relation between stock markets of crisis-hit counties and stock markets in the rest of the world is positive in tranquil times and becomes less positive in times of crisis.

One of the key implications of these empirical findings for investors is that debt crises in other countries lead to losses in their stock portfolios whether they are invested in the investors' home country or in a foreign country. Investors also need to be cognizant of the fact that, since contagion is generally systemic across world stock markets, international diversification does not necessarily hedge their portfolios during times of significant debt crises. The finding that the contagion from the crisis-hit bond markets to stock markets in the rest of the world is much larger in magnitude than the contagion from

\footnotetext{
${ }^{9}$ The robustness checks included (1) using return shocks instead of raw equity returns, (2). additional lags of own returns in the VAR models, and (3) using sovereign bond yield changes and stock returns of an expanded set of six eurozone countries (Portugal, Ireland, Italy, Greece, Spain, and Cyprus) instead of the four countries (Portugal, Ireland, Greece, and Cyprus). The results and conclusions are remarkably robust to these alternative specifications.
} 
crisis-hit stocks markets to other stocks markets suggests that investors should also consider the risks of sovereign bond markets in assessing the risks and timing of equity market exposure and in periodic portfolio rebalancing. Given the existence of negative contagion, the results imply that macroeconomic analysis of major foreign economies should be an inherent part of even investing in domestic equities, let alone international investments, so as to understand the potential for impending financial, economic, currency and debt crisis.

It is also important to note that while the contagion from crisis-hit bond markets is negative during the crisis, the magnitude of such contagion is generally lower than that during normal times. Similarly, although stock markets around the world decline as crisis-hit stock markets decline in response to debt crisis, the magnitude of such decline is much less compared with normal times. In other words, while contagion from the debt crisis is negative for stock markets, stock markets are less sensitive to such negative shocks relative to their sensitivity during normal times. Thus, the interesting implication for investors is that their stock portfolios, both domestic and foreign, decline by a lower magnitude during crisis compared to normal times. The apparent decoupling of stock markets during the crisis provides a justification for creating internationally diversified portfolios. To be sure, international diversification does not mitigate portfolios against systematic risks emanating from events such as the eurozone debt crisis. But such portfolios seems to have less sensitivity to negative contagion associated with the eurozone debt crisis.

The international transmission of negative shocks in crisis-hit bond and stock markets also have enormous implications for fiscal, monetary, and exchange rates policies of governments. For many emerging markets, the decline in their stock markets as a consequence of systemic negative contagion from the debt crisis could lead to net outflows of foreign portfolio investments resulting in depletion of foreign exchange reserves and depreciation of their currencies with associated macroeconomic problems. The resulting weaker investment environment makes it difficult for emerging markets to attract much needed foreign capital and float government bonds to raise external funds needed for budgetary purposes. Further, decline in government revenue due to weak economic conditions, and as a consequence, rising budget deficits tend to exacerbate economic problems. On the other hand, as we have experienced in the U.S., relatively less risky markets may attract the capital fleeing from other markets causing their bond markets and stock markets to rise due to increased demand and the currencies to appreciate due to increased foreign capital. The above polar-opposite repercussions for emerging and the U.S. economies mean that negative contagion ultimately impacts the monetary policy responses of the central banks, whether it is raising interest rates in response to improved economic conditions in the case of the U.S. or raising interest rates to prevent currency depreciations in the case of emerging markets. The negative contagion also must be considered in designing the regulatory frameworks to mitigate unintended consequences of financial market and capital account liberalization.

\section{Conclusions}

This paper examines the contagion of the eurozone debt crisis to developed and emerging stock markets around the world. The contagion is defined as the incremental impact of the crisis on equity markets, and is estimated through a VAR framework that uses changes in sovereign bond yields and stock returns of the crisis countries of Greece, Ireland, Portugal, and Cyprus as proxies for the eurozone debt crisis. This paper contributes to the literature by developing a straightforward framework for understanding contagion of the eurozone debt crisis, and by providing empirical evidence on the contagion from the crisis countries to other developed and emerging stock markets.

The main results show that changes in sovereign bond yields are strongly positively associated with equity returns during normal times, and this large positive effect reverses to a large negative effect during the eurozone crisis, providing strong evidence of negative contagion from sovereign bond markets of crisis countries to other equity markets. This evidence is consistent with the "risk-on risk-off hypothesis" where investors tend to engage in high-risk investments when risk is perceived as low and exit from risky investments when risk is perceived as high. The results also show that equity returns of crisis countries and the other markets are strongly positively related during normal times, and this relation becomes significantly less positive during the debt crisis. This evidence of negative contagion from equity markets of crisis countries to equity markets of other countries supports the decoupling hypothesis. The Asian markets do not show pervasive evidence of contagion from the eurozone debt crisis.

\section{References}

Bae, K.H., Karolyi, G.A., Stulz, R.M., 2003. A new approach to measuring financial contagion. Rev. Financ. Stud. 16, 717-763.

Baele, L., 2005. Volatility spillover effects in European equity markets. J. Financ. Quant. Anal. 40, $373-401$.

Bekaert, G., Harvey, C.R., Ng, A., 2005. Market integration and contagion. J. Bus. 78, 39-69.

Black, L., Correa, R., Huang, X., Zhou, H., 2013. The Systemic Risk of European Banks during the Financial and Sovereign Debt Crises. Board of Governors of the Federal Reserve System International Finance Discussion Papers Number 1083.

Constancio, V., 2012. Contagion and the European debt crisis. Financ. Stabil. Rev. 16, 109-121.

Cuadro-Saez, L., Fratzscher, M., Thimann, C., 2009. The transmission of emerging market shocks to global equity markets. J. Empirical Financ. 16, 2-17.

Edwards, S., 2000. Contagion. Working Paper, NBER.

Eun, C.S., Shim, S., 1989. International transmission of stock market movements. J. Financ. Quant. Anal. 24, $241-256$.

Forbes, K., Rigobon, R., 2001. Measuring contagion: conceptual and empirical issues. In: Claessens, Stijn, Forbes, Kristin J. (Eds.), International Financial Contagion. Kluwer Academic Publishers, Norwell, MA.

Forbes, K., Rigobon, R., 2002. No contagion, only interdependence: measuring stock market comovements. J. Financ. 57, 2223-2261.

Glover, B., Richards-Shubik, S., 2014. Contagion in the European Sovereign Debt Crisis. National Bureau of Economic Research Working Paper 20567.

Hamao, Y., Masulis, R.W., Ng, V., 1990. Correlations in price changes and volatility across international stock markets. Rev. Financ. Stud. 3, 281-308. 
Karolyi, G.A., 2003. Does international financial contagion really exist? Int. Financ. 6, 179-199.

Karolyi, G.A., Stulz, R.M., 1996. Why do markets move together? An investigation of U.S.-Japan stock return comovements. J. Financ. 51, 951-986.

King, M., Wadhwani, S., 1990. Transmission of volatility between stock markets. Rev. Financ. Stud. 3, 5-33.

Lee, S.B., Kim, K.J., 1993. Does the October 1987 crash strengthen the co-movements among national stock markets? Rev. Financ. Econ. 3, 89-102.

Lin, W.L., Engle, R.F., Ito, T., 1994. Do bulls and bears move across borders? International transmission of stock returns and volatility. Rev. Financ. Stud. 7 , 507-538.

Longin, F.M., Solnik, B., 1995. Is the correlation in international equity returns constant: 1960-1990? J. Int. Money Financ. 14, 3-26.

Missio, S., Watzka, S., 2011. Financial Contagion and the European Debt Crisis. Ludwig-Maximilian-University of Munich Working paper.

Samarakoon, L.P., 2011. Stock market interdependence, contagion, and the U.S. financial crisis: the case of emerging and frontier markets. J. Int. Financ. Markets Inst. Money 21, 724-742. 